\title{
Seasonal distribution and foraging occurrence of Cook Inlet beluga whales based on passive acoustic monitoring
}

\author{
Manuel Castellote ${ }^{1,2, *}$, Robert J. Small ${ }^{3}$, Marc O. Lammers ${ }^{4}$, Justin Jenniges ${ }^{5}$, \\ Jeffrey Mondragon ${ }^{3}$, Christopher D. Garner ${ }^{6}$, Shannon Atkinson ${ }^{7}$, \\ Jade M. S. Delevaux ${ }^{4}$, Richard Graham ${ }^{8}$, Delmar Westerholt ${ }^{9}$
}

\footnotetext{
${ }^{1}$ Joint Institute for the Study of the Atmosphere and Ocean (JISAO), University of Washington, Seattle, WA 98105, USA ${ }^{2}$ Marine Mammal Laboratory, Alaska Fisheries Science Center, National Marine Fisheries Service, Seattle, WA 98115, USA ${ }^{3}$ Alaska Department of Fish and Game, Juneau, AK 99811, USA ${ }^{4}$ Oceanwide Science Institute, Honolulu, HI 96839, USA ${ }^{5}$ Alaska Department of Fish and Game, Douglas, AK 99824, USA

${ }^{6}$ Joint Base Elmendorf Richardson, US Air Force Conservation Department, 673 CES CEIEC, JBER, Anchorage, AK 99506, USA

${ }^{7}$ School of Fisheries and Ocean Sciences, University of Alaska Fairbanks, Juneau, AK 99801, USA ${ }^{8}$ Colorado State University, Fort Collins, CO 80523-1490, USA ${ }^{9}$ Off The Bottom, Anchorage, AK 99508, USA
}

\begin{abstract}
A paucity of information on the basic biology and ecology of Cook Inlet beluga whales Delphinapterus leucas remains a decade after the species was listed as endangered in 2008. The causes of its continued decline remain unclear. This lack of knowledge limits our understanding of, and ability to manage, potential threats impeding the recovery of this endangered population. Seasonal distribution and foraging ecology, particularly during winter, are currently among the most basic gaps in knowledge. Therefore, we conducted a year-round passive acoustic monitoring program from 2008-2013, monitoring 13 locations within the belugas' critical habitat. We identified seasonal occurrence patterns across years at most locations. Detections were higher in the upper inlet during summer, peaking in known concentration areas. The occurrence of whales in the upper inlet when ice coverage peaked during winter was more prevalent than previously suggested. We documented seasonal differences in foraging habitat preference, with foraging behavior more prevalent during summer, particularly near upper inlet rivers, than during winter. Foraging peaks coincided with the presence of different anadromous fish runs from spring to fall. Low levels of feeding activity in winter suggest a lack of feeding aggregation areas, feeding in non-monitored offshore waters, or increased effort on benthic prey. These results represent a substantial contribution to our knowledge of Cook Inlet beluga seasonal distribution and foraging ecology, which will strengthen conservation and management strategies and thus more effectively promote recovery of this endangered population.
\end{abstract}

KEY WORDS: Cook Inlet beluga - Passive acoustic monitoring - Seasonal distribution . Foraging behavior

\section{INTRODUCTION}

Of the 5 populations of beluga whale Delphinapterus leucas recognized by US NOAA Fisheries in Alaska, the most isolated is in Cook Inlet (Hill \& DeMaster 1998). This population is genetically dis-

\footnotetext{
${ }^{*}$ Corresponding author: manuel.castellote@noaa.gov
}

tinct (O'Corry-Crowe et al. 1997), and aerial surveys and satellite telemetry have shown that the whales remain in the Cook Inlet area all year (Rugh et al. 2000, Hobbs et al. 2005). Almost the entire population is found only in northern waters of the inlet from late spring through summer and into fall (Shelden et 
al. 2018). They congregate in shallow, low-salinity water near major river outflows (defined as their primary habitat), where predator occurrence is relatively low and prey availability seems comparatively high (Moore \& DeMaster 2000). There is very limited knowledge on diet for this population, mainly gained from traditional knowledge and stomach contents sampled during subsistence harvests. Their main prey include several species of Pacific salmon, with coho Oncorhynchus kisutch showing the highest proportion in stomachs (but preference for sockeye Oncorhynchus nerka is listed in traditional knowledge reports), followed by cod species (Arctic cod Boreogadus saida, saffron cod Eleginus gracilis, walleye pollock Theragra chalcogramma, and Pacific cod Gadus macrochephalus), eulachon Thaleichthys pacificus, and flounder (Pleuronectidae) (Quakenbush et al. 2015, Huntington 2000). Invertebrate prey are less prevalent in the Cook Inlet belugas' diet than in other Alaska stocks (Quakenbush et al. 2015). In winter, limited information indicates dispersal towards the central and lower inlet, but sightings are fewer in number and whales are dispersed compared to summer. There is no knowledge of winter diet or prey preferences.

The geographic and genetic segregation of this stock, combined with the belugas' tendency toward site fidelity in summer, makes this population especially vulnerable to impacts from large or persistent harvests (Moore \& DeMaster 2000). Following population abundance estimates that indicated a decline of nearly $50 \%$ from 1994 (653 whales, CV $=0.24$ ) to 1998 (347 whales, CV $=0.17$ ), due primarily to an unregulated subsistence harvest, the Cook Inlet beluga whale stock was designated as depleted under the Marine Mammal Protection Act in 2000 (NMFS 2000). Subsequent cooperative management efforts between the US National Marine Fisheries Service (NMFS) and Alaska Native subsistence users dramatically reduced the harvest (Mahoney \& Shelden 2000). However, 2 decades later, the number of whales continues to decline at a $-2.3 \% \mathrm{yr}^{-1}$ (estimated range between $-4.1 \%$ to $-0.6 \%$ annual rate), with a current estimated population size between 250 and 317, with a median estimate of 279 (Shelden and Wade 2019), indicating that unless the factors impeding recovery are determined and mitigated, this beluga whale population may become extinct (Hobbs et al. 2006). Therefore, in 2008 the NMFS determined that the Cook Inlet beluga whale distinct population segment was endangered as defined by the US Endangered Species Act (NMFS 2008a). Based on distribution data from dedicated aerial sur- veys in June and July over the past 3 decades, the belugas' summer range has contracted substantially in all but the area with the highest degree of human disturbance off the city of Anchorage (Rugh et al. 2010). Further, range contraction has been documented outside the summer period, based on a review of data from aerial surveys, satellite-tagging, and opportunistic sightings (Shelden et al. 2015). A recovery plan was drafted following the endangered listing status (NMFS 2016), yet the minimal available data, and associated uncertainty, precluded determination of the factors and mechanisms of negative effects by threats currently impeding recovery. However, the plan did identify, describe, and rank (i.e. level of concern) general threats to recovery and highlighted the need for further basic information on Cook Inlet beluga whale biology and ecology to improve our understanding of, and ability to manage, those threats.

Seasonal distribution and foraging ecology are among the current knowledge gaps for the Cook Inlet beluga whale population. Summer distribution has been well studied, primarily in the upper inlet (NMFS 2008b). However, knowledge of the whales' distribution during fall, winter, and early spring is very limited because of the combination of poor sighting conditions (low light levels, white whales among ice floes) and whale behavior (closer association with ice, longer and deeper diving patterns, smaller groups) making visual detection difficult (Shelden et al. 2015). Satellite telemetry data from 1999-2003 provided limited insights into their spatial distribution outside the summer period (JuneSeptember) based on a small sample of adult males; only 4 tags remained active until February, and one into May (Hobbs et al. 2005). An even greater paucity of information exists on the foraging ecology of Cook Inlet beluga whales. The limited 1999-2003 telemetry data provides a description of some general foraging areas, based on slow transit and short diving behavior (Goetz et al. 2012). Other than this, data on beluga whale foraging behavior in Cook Inlet is basically non-existent. While recognizing the important results from the limited research efforts described above, a substantive increase in our understanding of beluga whale seasonal distribution and foraging ecology is required to develop an effective recovery strategy for this endangered population.

To address this information need, the Cook Inlet Beluga Acoustics (CIBA) research program was initiated in 2008 with the primary objective of examining the year-round seasonal distribution and foraging oc- 
currence of beluga whales, based on several consecutive years of passive acoustic monitoring. In contrast to visual efforts in Cook Inlet, acoustic monitoring is less limited by weather, surface conditions, turbidity, ice presence, and low light levels, and is thus able to provide continuous observations of cetacean activity near an instrument mooring site. However, Cook Inlet is a notoriously challenging environment to maintain long-term anchored moorings (e.g. extreme tidal range and currents, extreme sedimentation from glacial silt, bed load transport by currents, ice, and vegetative debris). Therefore, the CIBA research program invested substantial effort in designing and testing passive acoustic mooring packages that could withstand these harsh environmental conditions and obtain reliable beluga whale acoustic detection data, as explained in detail by Lammers et al. (2013) and Castellote et al. (2016). The latter 2 publications present the proof of concept for the passive acoustic monitoring methods used in the CIBA monitoring program. Here, we present final results on the seasonal presence in the monitored locations of the Cook Inlet beluga whale's critical habitat, as well as foraging occurrence based on echolocation activity, obtained year-round over a 5 yr period.

\section{MATERIALS AND METHODS}

\subsection{Acoustic monitoring instruments and mooring locations}

Custom-designed low-profile moorings were used to withstand the harsh environmental conditions of Cook Inlet (Lammers et al. 2013, Castellote et al. 2016). Moorings contained 2 instruments: (1) ecological acoustic recorders (EARs; Hawaii Institute of Marine Biology) that monitored the $0-12.5 \mathrm{kHz}$ frequency range to record ambient sound including beluga whale Delphinapterus leucas social signals, and (2) cetacean and porpoise detectors (C-PODs; Chelonia Limited) that monitored the $20-160 \mathrm{kHz}$ frequency range to log beluga whale echolocation clicks. Monitoring both social signals and echolocation maximized beluga whale detections (Castellote et al. 2016).

We deployed acoustic moorings at 13 locations within Cook Inlet beluga whale critical habitat during 2008-2013 (Fig. 1). Our monitoring locations were chosen based on several factors: (1) deploying moorings in all major regions of designated critical habitat, with an emphasis on the upper inlet; (2) logistical challenges (i.e. strong currents, shallow waters, ice presence) associated with deploying and recovering moorings using a relatively small vessel $(9 \mathrm{~m}$ in length) in the upper Inlet; (3) limited number of acoustic instruments; and (4) collaboration with other beluga whale researchers to conduct spatially and temporally concurrent acoustic and visual monitoring of beluga whales. Based on these criteria, we selected 6 monitoring locations distributed from Homer Spit in the lower Inlet to Fire Island in the upper Inlet (Fig. 1); these 6 locations were within $\sim 2-16 \mathrm{~km}$ offshore at mean high tide, in addition to a location in the Little Susitna River $\sim 4 \mathrm{~km}$ upstream from the river mouth. The 6 remaining locations were in Knik Arm (northeast end of Cook Inlet). Pilot studies experienced high mooring loss in Knik Arm during the winter, presumably due to extensive ice coverage shifting and gauging in the relatively shallow waters ( 0 to $\sim 7 \mathrm{~m}$ at low tide). Thus, we selected multiple locations with bathymetric features that would presumably decrease the likelihood of mooring loss in this area (i.e. bottom of valleys, areas protected from main flow by sand bars, etc.). No moorings were deployed in Turnagain Arm because of substantial logistical and environmental challenges.

Based primarily on ice phenology in Cook Inlet, we defined 2 seasons: 'summer', the ice-free period from May-October, and 'winter', the freezing to melting period from November-April. We chose a semiannual deployment and recovery schedule for all monitoring locations based on ice conditions. Specifically, recovery and redeployment was not logistically feasible sooner than April or May, nor later than October or early November for upper Inlet locations. Based on this schedule, we programmed the EARs to record for $30 \mathrm{~s}$ every $5 \mathrm{~min}$ (i.e. $10 \%$ duty cycle) and the C-PODs to monitor continuously (Lammers et al. 2013, Castellote et al. 2016). We anticipated these configurations would exhaust the EAR batteries and fill C-POD data storage near the end of each $\sim 6$ mo deployment.

\subsection{Quantifying beluga whale presence}

Acoustic monitoring effort varied substantially by location and across months throughout the overall monitoring period, primarily because one or both of the EAR or the C-POD devices stopped recording for a variety of reasons before moorings were recovered (see Fig. 2). The most common reasons included variation in battery duration, maximum memory capacity being reached, water leaking into the instrument housing, and instrument electronics failure. We quantified differences in monitoring effort by defin- 


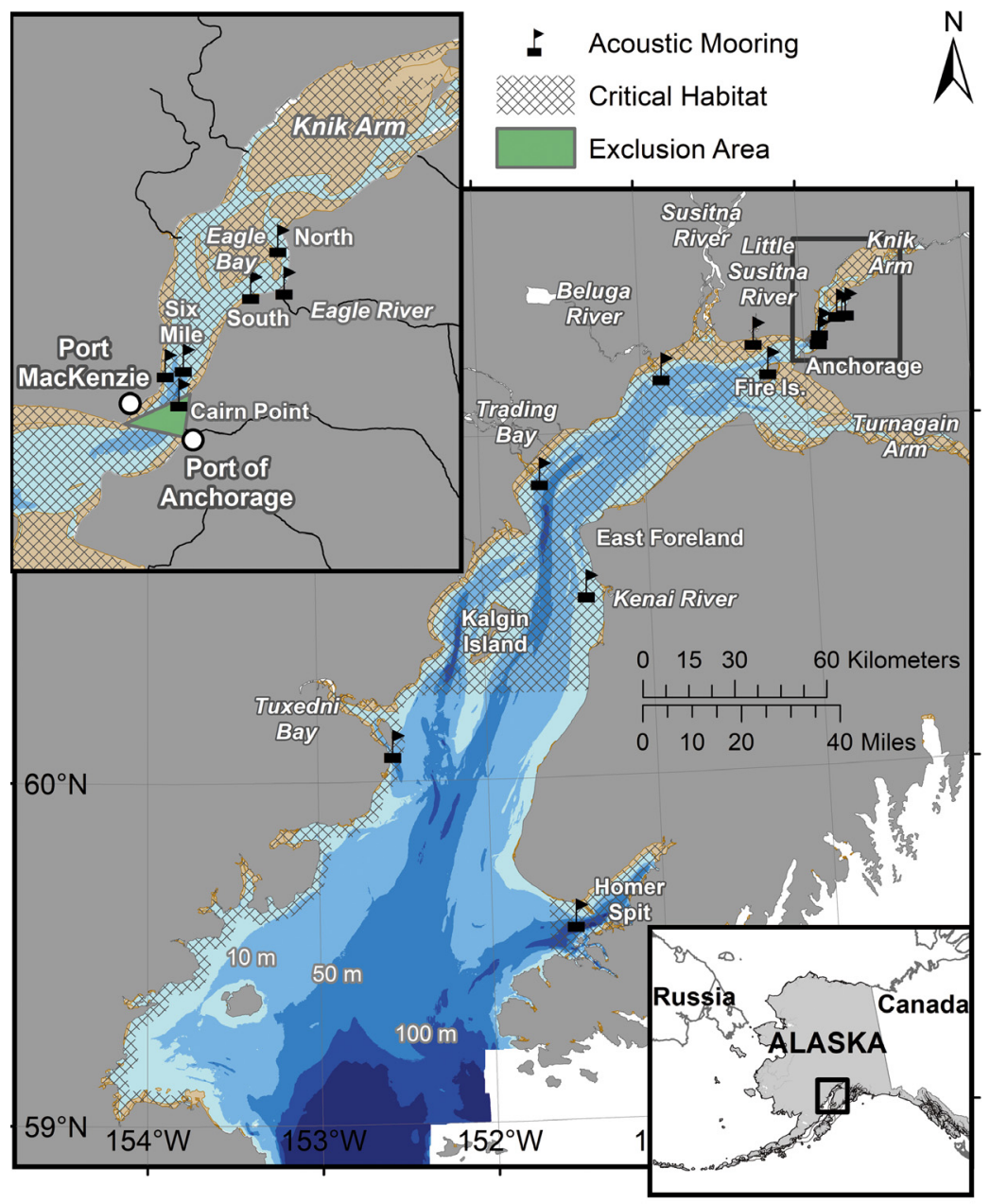

Fig. 1. Locations where acoustic moorings were deployed to monitor beluga whales from July 2008 to May 2013, in Cook Inlet, Alaska. Upper left insert: 6 deployment sites in Eagle Bay $(n=3)$ and lower Knik Arm $(n=3)$. Map includes Cook Inlet beluga critical habitat, its exclusion area in Knik Arm, and the mud flats exposed at low tide (brown shading)

ing an acoustic effort hour (AEH) as any hour for which the EAR and/or C-POD recorded properly for $\geq 1$ min (short recording periods only occurred at the beginning or end of a data set); both instruments recording in the same hour resulted in only 1 , not 2 , AEHs. All EARs were programmed to record at a sampling rate of $25 \mathrm{kHz}$ on a $10 \%$ duty cycle of $30 \mathrm{~s}$ on every 5 min; C-PODs monitored echolocation continuously in the frequency range $20-160 \mathrm{kHz}$. Both instruments remained active throughout the deployment period or until battery or memory was exhausted (see Fig. 2).

Beluga whale signals in the data were identified using analysis methods described in detail in Lammers et al. (2013) for EAR data and in Castellote et al. (2016) for C-POD data. In summary, EAR data were analyzed using the MATLAB script Triton (Sean Wiggins, Scripps Institution of Oceanography) which was adapted for use with EAR data. Triton was used to create long-term spectral averages (LTSAs) of the recordings for each deployment. We used a fixed LTSA window length of $6 \mathrm{~h}$. The LTSA was based on $10 \mathrm{~s}$ averages, corresponding to a resolution of 216 slices per $6 \mathrm{~h}$ window. Beluga and killer whale Orcinus orca encounters were identified by visually examining the LTSA for the presence of 'hot spots' of acoustic energy in the frequency bands associated with whale signals. We then zoomed into these to confirm the detection using a 1024 point Hanningwindowed spectrogram of the original recording. The analysts investigated any spectral pattern that was even remotely consistent with beluga calling, even faint signals. Because beluga calls are rarely emitted in isolation, when a call was detected the analyst went backward and forward in time to establish exactly when the first and last calls occurred in the encounter. Therefore, faint calls in an encounter were not missed. It is conceivable that calls from distant belugas at the very edge of detectability that never approached the mooring could have been missed, but that would have corresponded to animals at the edge of the mooring's effective detection range. C-POD data were analyzed using C-POD.exe v.2.043 (Chelonia Limited). All click train detections were manually validated by plotting the peak click frequency in the CPOD.exe analysis window with a time resolution of $100 \mathrm{~ms}$. Click train type classification (narrowband high frequency clicks from porpoises, or other cetacean clicks) was also manually validated for each click train in the CPOD.exe analysis window based on differences in peak frequency and click bandwidth among the echolocation clicks of belugas, killer whales, and porpoises (Dall's porpoise Phocoenoides dalli, and harbor porpoise Phocoena phocoena). Only beluga, killer whale, and porpoises (both harbor and Dall's) inhabit Cook Inlet on a regular basis (Shelden et al. 2015). The acoustic behavior of these species is distinct, and the properties of their echolocation signals are readily distinguishable (Au 1993).

We estimated beluga whale presence on an hourly basis. Specifically, any hour in which a beluga whale 
echolocation click train, call, or whistle was detected, by either an EAR or C-POD, was categorized as a detection positive hour (DPH). As such, a DPH could include a single type of beluga whale signal, or up to all 3 types (echolocation, calls, and whistles), and could include signals at different rates (e.g. one single call or many calls). This DPH approach reduced behavioral effects when quantifying beluga whale presence (e.g. avoided using number of clicks as a metric of presence). To summarize beluga presence across the $5 \mathrm{yr}$ of sampling for each deployment site, weekly means of daily DPHs were calculated and plotted. Days where sampling was truncated (i.e. less than $24 \mathrm{~h}$ of data were available) were omitted for the calculation of weekly means of daily DPHs. This only occurred on the first and last day of sampling. Fully sampled days (i.e. $24 \mathrm{~h}$ ) included in the calculation could account for effort from the EAR, the C-POD, or both instruments, as described in the definition of a DPH. To account for differences in sampling efforts across sites or within sites across seasons, we normalized beluga whale presence as the percentage of DPHs over total AEHs:

$$
\% \mathrm{DPH}=(\mathrm{DPH} \times 100) / \mathrm{AEH}
$$

We calculated \%DPH separately for each of the mooring locations in the upper and lower Inlet. However, for Knik Arm locations, due to lost moorings or instrument failure in several of the 6 locations, monitoring durations were shorter and thus AEH and DPH were smaller, so data were pooled for the deployment sites. North Eagle Bay, South Eagle Bay, and Eagle River Mouth became 'Eagle Bay', and Six Mile, Port MacKenzie, and Cairn Point became 'Lower Knik Arm' (see Fig. 2). We calculated \%DPH in these 2 pooled areas, assuming they would not be detected on more than one mooring at one time, by dividing the sum of all DPHs from the moorings in each area by the number of non-overlapping AEHs to avoid replicated effort hours between pooled data sets. Finally, we calculated the median, $5^{\text {th }}$, and $95^{\text {th }}$ percentiles of \%DPH during summer and winter in Eagle Bay, Lower Knik Arm, and the 7 upper and lower Cook Inlet locations.

\subsection{Quantifying beluga whale foraging occurrence}

Echolocation data provide an opportunity to assess when foraging behavior occurs. Odontocetes emit a sequence of impulsive signals, termed clicks, and receive the echo from the target prey to interpret its distance and location. Each sequence of clicks is termed a click train (Au 1993). When odontocetes echolocate on prey, their acoustic beam is locked on the target prey during the pursuit and capture phases (Verfuß et al. 2009), which represent foraging behavior. During the capture phase, the inter-click interval (ICI) between consecutive clicks in a click train is reduced and often ends with a burst of clicks known as a terminal buzz (Griffin et al. 1960, Miller et al. 1995). Previous studies on beluga whales have proposed a minimum ICI of $2 \mathrm{~ms}$ or less for click trains related to prey pursuit and capture (Roy et al. 2010, Castellote et al. 2013). Thus, in our study we analyzed C-POD data and identified all click trains with a minimum ICI of $2 \mathrm{~ms}$ or less. However, studies on other odontocete species have shown ICIs well in excess of $2 \mathrm{~ms}$ during feeding echolocation behavior (e.g. beaked whales, Johnson et al. 2004; harbor porpoises, DeRuiter et al. 2009, Wisniewska et al. 2014), thus we assume the ICI threshold applied here is conservative. Also, some studies on dolphin species emitting both whistles and pulsive signals have identified the use of burst pulses with ICIs of less than $2 \mathrm{~ms}$ to be associated with social interactions (e.g. Herzing 1995, Murray et al. 1998); however, these occur within the frequency range of social communication, well below echolocation frequencies and the frequencies sampled by the C-POD. We deleted click trains with minimum ICI less than $1 \mathrm{~ms}$, because multipath propagation of sound waves may result in double clicks due to different delays arriving at the C-POD along different paths, e.g. by reflections from the water surface (Koschinski et al. 2008, Roy et al. 2010). The EARs recorded ambient sound and social vocalizations below $12.5 \mathrm{kHz}$, and were not used for identifying foraging behavior.

Similar to our treatment of DPH to minimize behavioral effects, rather than using the absolute number of foraging click trains to estimate foraging occurrence, we classified each minute when at least one foraging click train was detected as a foraging positive minute (FPM). When there were $<3 \mathrm{FPM} \mathrm{mo}^{-1}$, the associated data were manually verified to confirm that $>1$ terminal buzz was detected within each FPM; only FPMs with $>1$ feeding buzz were accepted for further analysis. We then created a foraging index, normalizing the occurrence of foraging behavior by dividing FPM by the amount of beluga time presence (i.e. DPHs), excluding time when C-POD instruments were not active (as foraging would not be monitored):

$$
\text { Foraging index }=\mathrm{FPM} \times 100 / \mathrm{DPH}
$$


The duration of foraging behavior is extremely short, thereby making the index value too small when presented next to \%DPH, so we used a subjective multiplying factor of 100 to graphically compare the index across sites or periods. This scaling allows foraging behavior to be compared among the different monitoring locations where DPHs varied substantially. We calculated the monthly foraging index inlet-wide by using the sum of all FPMs and DPHs (excluding time when C-POD instruments were not active) from all sites combined per month. Finally, we also calculated the foraging index per site by summer and winter periods.

\section{RESULTS}

\subsection{Acoustic effort}

All 6 mooring locations in upper and lower Cook Inlet outside Knik Arm (Homer Spit, Tuxedni Bay, Kenai River, Trading Bay, Beluga River, and Fire Island) were monitored during both summer and winter (Table 1, Fig. 2). The location $\sim 4 \mathrm{~km}$ up the Little Susitna River (upper Inlet) was successfully monitored during summer 2011 and was the only deployment at that location. Three moorings were not initially recovered in the upper Inlet (Fire Island, $\mathrm{n}=2$; Little Susitna, $\mathrm{n}=1$ ); however, all 3 were later found and their recordings were analyzed. Maintaining moorings in Knik Arm proved very challenging due to strong currents, large vegetative debris loads throughout the water column, sediment entrapment, and extreme ice conditions. In total, 15 moorings were lost initially (summer, $\mathrm{n}$ $=7$; winter, $\mathrm{n}=8$ ), of which 8 were later found washed ashore; overall, at least 1 mooring was lost at each of the 6 locations sampled in Knik Arm (Cairn Point, Point MacKenzie, Six Mile, South Eagle Bay, Eagle River, and North Eagle Bay). Overall, for all locations, 9 were monitored during both summer and winter, 3 during summer only, and 1 during winter only (Table 1, Fig. 2).

Across the entire study period, we obtained a total of 282441 AEHs (11768 d) for all locations from the EAR and C-POD data sets. In general, CPODs stopped logging earlier than EARs within the mooring deployment periods, yielding differences in the proportion of sampled effort (Table 2). When the 6 locations in Knik Arm were pooled into the Eagle Bay and Lower Knik Arm areas, we considered only one AEH when more than one $\mathrm{AEH}$ occurred in the same hour among pooled locations, which resulted in 236590 AEHs (9858 d), a 16.2\% decrease. On a monthly basis, acoustic effort was lower for months when the moorings were recovered and redeployed in spring and fall (Fig. 2). Specifically, instruments were typically serviced in April or May following an overwinter deployment and in October or November following a summer deployment, and recordings usually stopped for a short period ( 2-3 wk) prior to recovery, due to low power or full memory. Overall, the only gap in our monitoring effort was at Eagle Bay in upper Knik Arm during the 4 winter months of January through April (Fig. 2).
Table 1. The 13 locations in Cook Inlet, Alaska, where acoustic moorings were deployed to monitor beluga whales, July 2008 to May 2013. Coordinates (datum: WGS84), site depth $(1 \mathrm{ft}=0.3 \mathrm{~m})$, and successful and lost deployments by season are listed for each location

\begin{tabular}{|lccccc|}
\hline Location & $\begin{array}{c}\text { Latitude } \\
\left({ }^{\circ} \mathrm{N}\right)\end{array}$ & $\begin{array}{c}\text { Longitude } \\
\left({ }^{\circ} \mathrm{W}\right)\end{array}$ & $\begin{array}{c}\text { Depth } \\
(\mathrm{ft})\end{array}$ & $\begin{array}{c}\text { Successful and (lost) moorings } \\
\text { Summer }\end{array}$ & Winter \\
\hline North Eagle Bay & 61.336250 & 149.71870 & 30 & 5 & 1 \\
Eagle River Mouth & 61.328750 & 149.74417 & 20 & 8 & $1(1)$ \\
South Eagle Bay & 61.334430 & 149.77145 & 20 & 5 & 0 \\
Six Mile & 61.283330 & 149.88333 & 60 & 0 & $4(2)$ \\
Port MacKenzie & 61.273330 & 149.90892 & 80 & 3 & $3(2)$ \\
Cairn Point & 61.257830 & 149.89367 & 70 & $6(1)$ & $5(2)$ \\
Fire Island & 61.179170 & 150.21167 & 80 & $7(1)$ & 2 \\
Little Susitna & 61.267380 & 150.29150 & 27 & 1 & 0 \\
Beluga River & 61.177780 & 150.86333 & 55 & 5 & 3 \\
Trading Bay & 60.886670 & 151.62500 & 70 & 3 & 3 \\
Kenai River & 60.55500 & 151.37000 & 42 & 3 & 3 \\
Tuxedni Bay & 60.104170 & 152.54567 & 72 & 3 & 3 \\
Homer Spit & 59.59600 & 151.50333 & 60 & 3 & 3 \\
\hline
\end{tabular}

\subsection{Beluga whale presence}

For an initial assessment of beluga whale Delphinapterus leucas presence over the entire 5 yr monitoring period, we plotted the weekly means of daily DPHs in linear diagrams for each deployment location (Figs. 3 \& 4). Beluga whales were detected at 12 of 13 locations, with no detections at the southernmost location, Homer Spit. Annually, the maximum weekly mean of daily beluga whale DPHs was highest, ranging from 5-20, at Beluga River and Little Susitna, and 

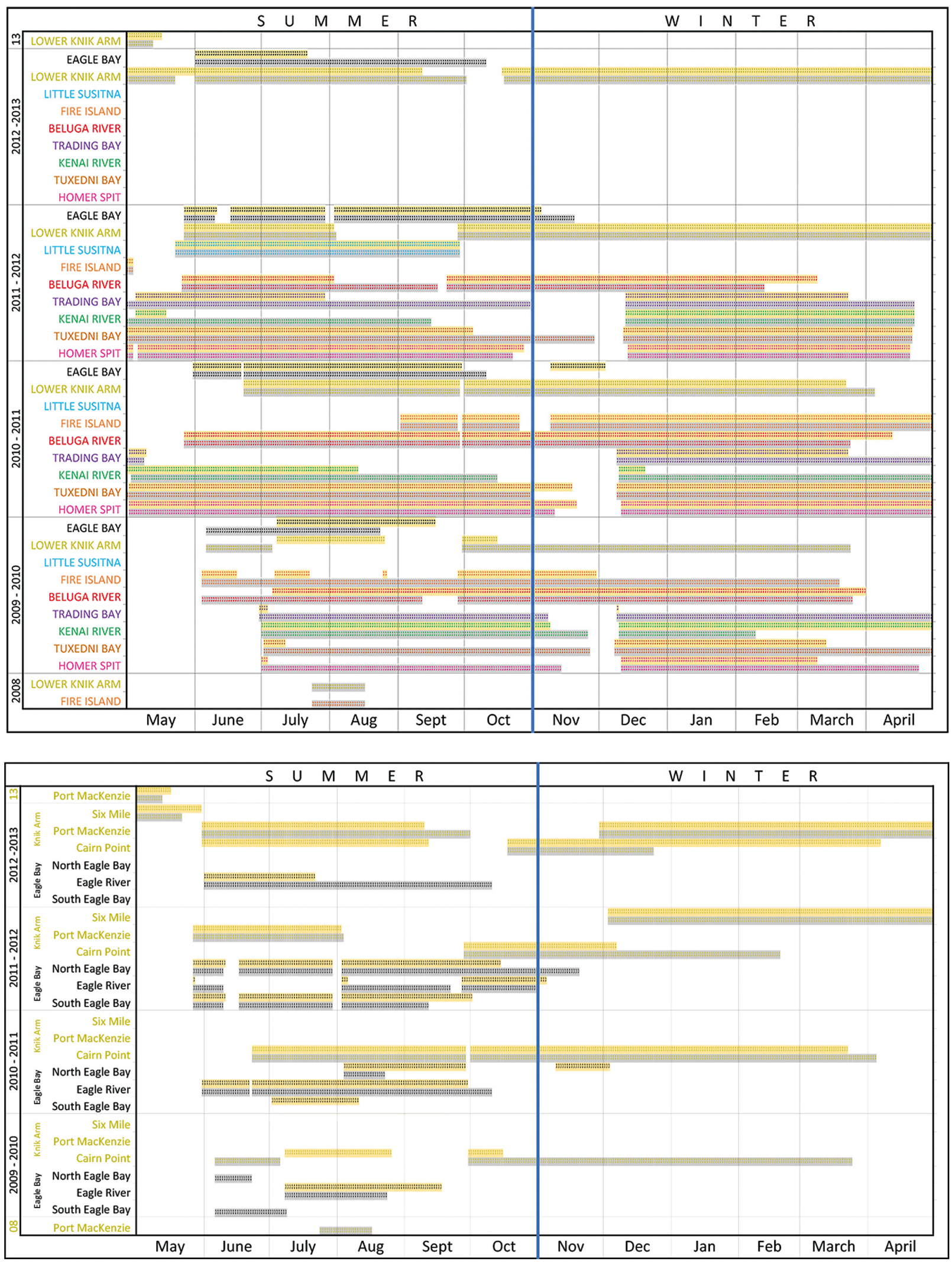

Fig. 2. Upper panel: beluga whale sampling effort by instrument type (grey: ecological acoustic recorders, EAR; yellow: cetacean and porpoise detectors, C-POD), location (different stippled colors for easier interpretation), month, and year, for acoustic moorings deployed in Cook Inlet, Alaska, July 2008 to May 2013. Months are organized by season, summer (MayOctober) and winter (November-April). Lower panel: Breakdown of sampling effort by instrument type, month, and year, for combined sites Eagle Bay and Lower Knik Arm 
Table 2. Proportion (\%) of total acoustic effort by instrument type per sampled location (see Fig. 1). EAR: ecological acoustic recorder; C-POD: cetacean and porpoise detector

\begin{tabular}{|lccccccccc|}
\hline $\begin{array}{l}\text { Instrument } \\
\text { type }\end{array}$ & $\begin{array}{c}\text { Eagle } \\
\text { Bay }\end{array}$ & $\begin{array}{c}\text { Lower } \\
\text { Knik Arm }\end{array}$ & $\begin{array}{c}\text { Fire } \\
\text { Island }\end{array}$ & $\begin{array}{c}\text { Little } \\
\text { Susitna River }\end{array}$ & $\begin{array}{c}\text { Beluga } \\
\text { River }\end{array}$ & $\begin{array}{c}\text { Trading } \\
\text { Bay }\end{array}$ & $\begin{array}{c}\text { Kenai } \\
\text { River }\end{array}$ & $\begin{array}{c}\text { Tuxedni } \\
\text { Bay }\end{array}$ & $\begin{array}{c}\text { Homer } \\
\text { Spit }\end{array}$ \\
\hline EAR & 79.2 & 76.8 & 100 & 100 & 91.8 & 100 & 89.7 & 98.3 & 98.7 \\
C-POD & 68.5 & 71.8 & 54.3 & 100 & 81.9 & 53.5 & 62.5 & 75.7 & 80.3 \\
\hline
\end{tabular}
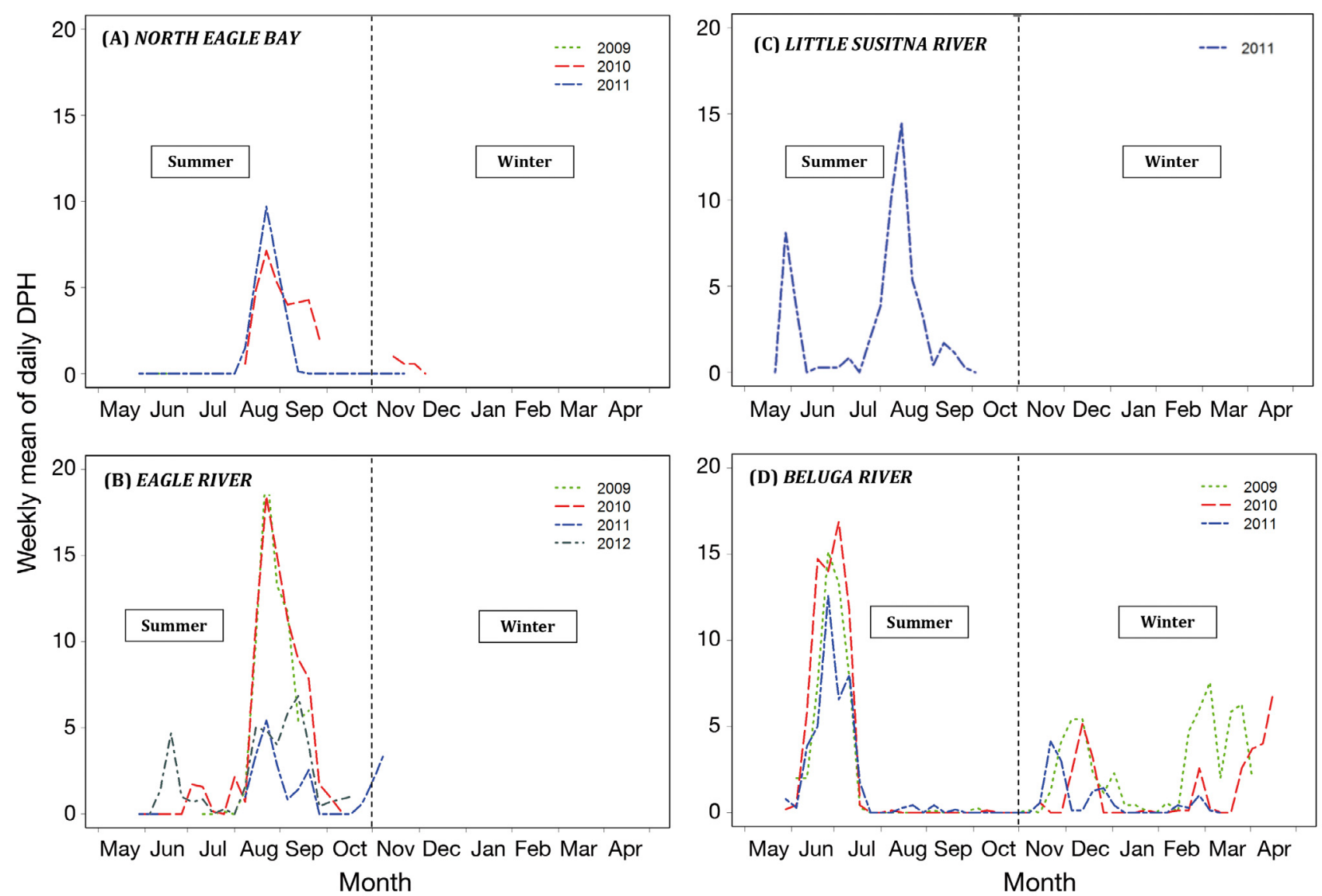

May Jun Jul Aug Sep Oct Nov Dec Jan Feb Mar Apr

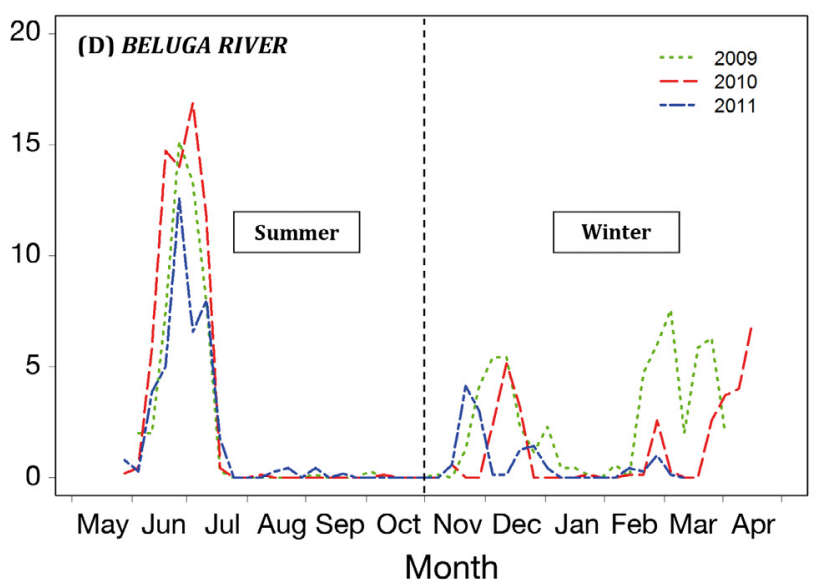

Fig. 3. Weekly mean of daily beluga whale detection positive hours (DPHs; range 0-20) from cetacean and porpoise detector (C-POD) and ecological acoustic recorder (EAR) combined detections, obtained at (A) North Eagle Bay, (B) Eagle River, (C) Little Susitna River, and (D) Beluga River in Cook Inlet, Alaska. Zero DPH values indicate there was acoustic effort but no belugas were detected, whereas the absence of DPH values indicates there was no acoustic effort and thus detections were not possible; lines that cross from December to January begin in the year noted by the color of the line (i.e. all fall redeployments)

the 3 locations in Eagle Bay (North Eagle Bay, Eagle River, and South Eagle Bay). Maximum weekly mean DPH was less than 5 at the 8 other locations. Seasonally, maximum weekly mean DPH occurred in summer near river mouths in the upper Inlet; i.e. Little Susitna, Eagle River, and Beluga River. Beluga whales were detected only during winter at the southernmost locations (i.e. Trading Bay, Kenai River, and Tuxedni Bay), and a few times in late summer (September and October) at Trading Bay.
At locations where recordings were obtained for $2 \mathrm{yr}$ or more, there was a relatively consistent annual pattern between seasons (e.g. surge in detections at Eagle River each fall, year after year; Fig. 3B). Several locations showed a similar pattern within seasons (e.g. increased feeding behaviors in lower Inlet sites during fall-winter). These patterns were more apparent at locations with maximum weekly mean DPHs ranging from 5-20 (Fig. 3). Specifically, in summer, beluga whale detections peaked during 


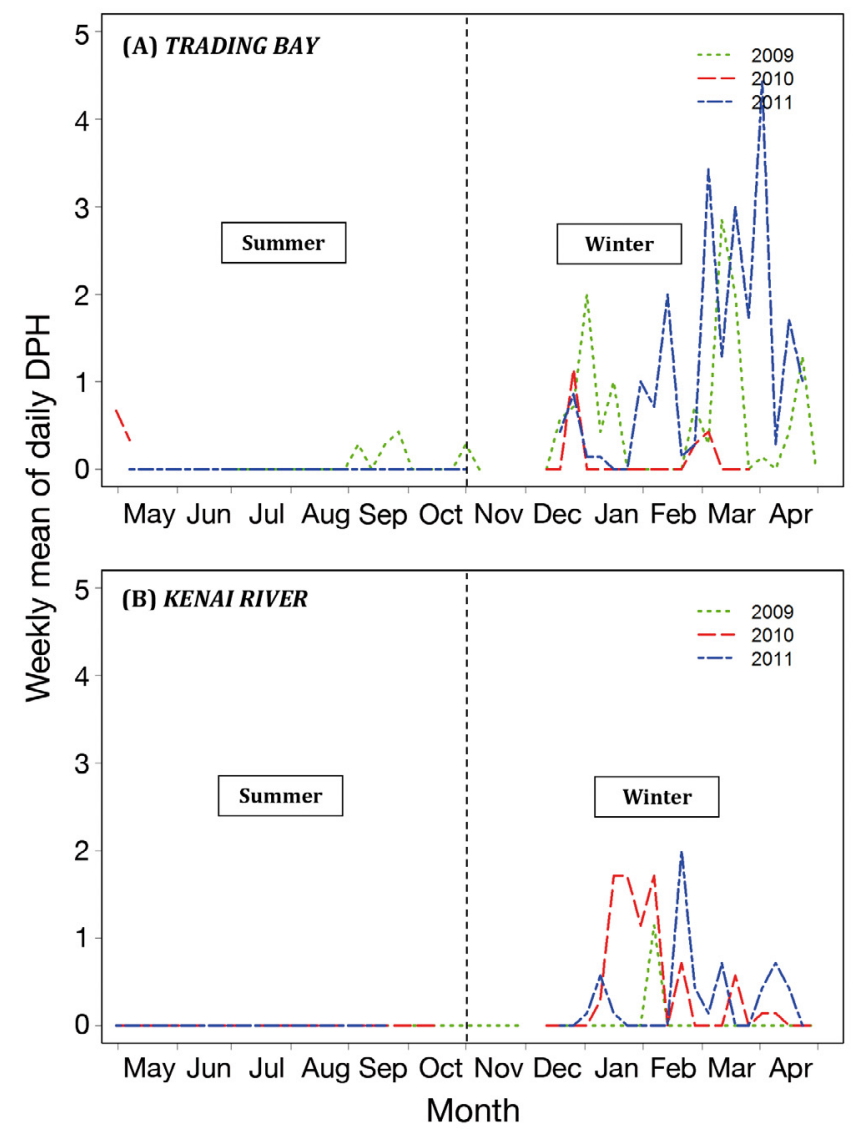

August-September at North Eagle Bay (Fig. 3A) and Eagle River (Fig. 3B), and at Beluga River during June-July (Fig. 3D); only the latter location had substantial winter acoustic effort (i.e. $>20000$ vs. $<1000 h_{\text {i }}$ see Fig. 2), and detections were consistently higher during November-December and FebruaryMarch. At locations with maximum weekly mean DPH $<5$ (Fig. 4), the only apparent within-season pattern was a peak from late February through early April at Tuxedni Bay (Fig. 4C) in 2010 and 2011 (but not 2009). A strong between-season pattern was evident at Trading Bay (Fig. 4A), Kenai River (Fig. 4B), and Tuxedni Bay (Fig. 4C), with detections only in winter, except for a few in August-October at Trading Bay, the more northern location.

When detections were normalized by acoustic sampling effort (i.e. Eq. 1), seasonal differences in beluga whale presence became clearly apparent (Fig. 5). On average, \%DPH in summer was more than twice that of winter; 26.0 vs. $11.6 \%$, respectively. The highest summer median \%DPH was at Eagle Bay $(2.5 \%)$, followed by Little Susitna River (2.3\%). The 7 other locations had median \%DPH values below $1 \%$; i.e. $<1$ detection per $100 \mathrm{~h}$ of effort. During winter, the highest beluga whale presence was at Beluga River (upper

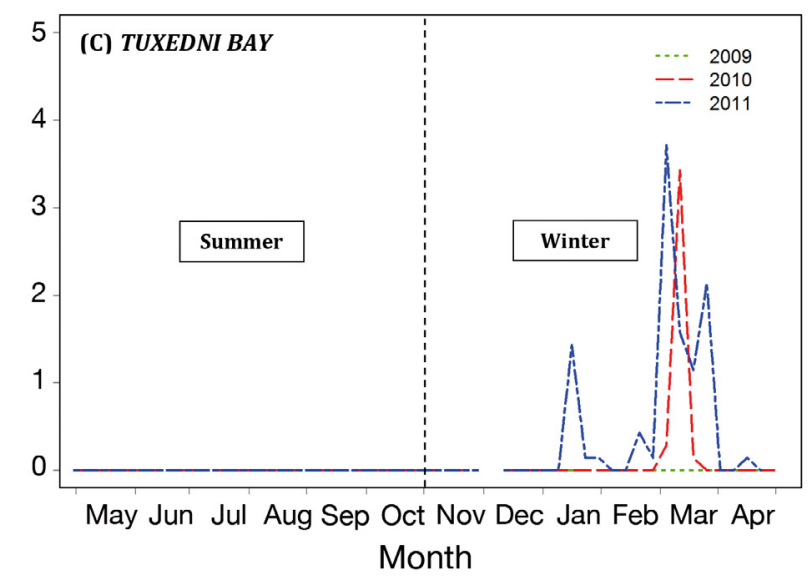

Fig. 4. Weekly mean of daily beluga whale detection positive hours (DPHs; range 0-5) from cetacean and porpoise detector (C-POD) and ecological acoustic recorder (EAR) combined detections, obtained at (A) Trading Bay, (B) Kenai River, and (C) Tuxedni Bay in Cook Inlet, Alaska. Zero DPH values indicate there was acoustic effort but no belugas were detected, whereas the absence of DPH values indicates there was no acoustic effort and thus detections were not possible; lines that cross from December to January begin in the year noted by the color of the line (i.e. all fall redeployments)

Inlet), with a \%DPH of $3.8 \%$, which is substantially higher than the $0.6 \%$ recorded during summer. There was a decrease in almost half the median \%DPH at Eagle Bay in winter, from $2.5 \%$ down to $1.3 \%$; however, winter sampling in this location was limited to only November and December (Fig. 2). Both Eagle Bay and Beluga River were among the 3 locations with highest \%DPH in both summer and winter (Fig. 5); Trading Bay had the second highest winter DPH at $1.3 \%$. Little Susitna was not monitored during winter. Similar to summer, the winter \%DPH at all other locations was $<1 \%$. During summer, beluga whales were not detected at Kenai River, and DPH\% was only $0.1 \%$ at Trading Bay and Tuxedni Bay, yet during winter \%DPH increased at each of these 3 locations, to $0.4,1.3$, and $0.1 \%$, respectively. Beluga whales were never detected at Homer Spit, during either summer or winter, despite having 39315 AEHs (Fig. 2) during year-round monitoring over $3 \mathrm{yr}$.

The spatial distribution of our year-round acoustic monitoring effort along with beluga whale detections for all of Cook Inlet is shown in Figs. 6 \& 7. There were minimal AEHs at Little Susitna and Fire Island during winter because the moorings were only deployed for a few months or were lost. 


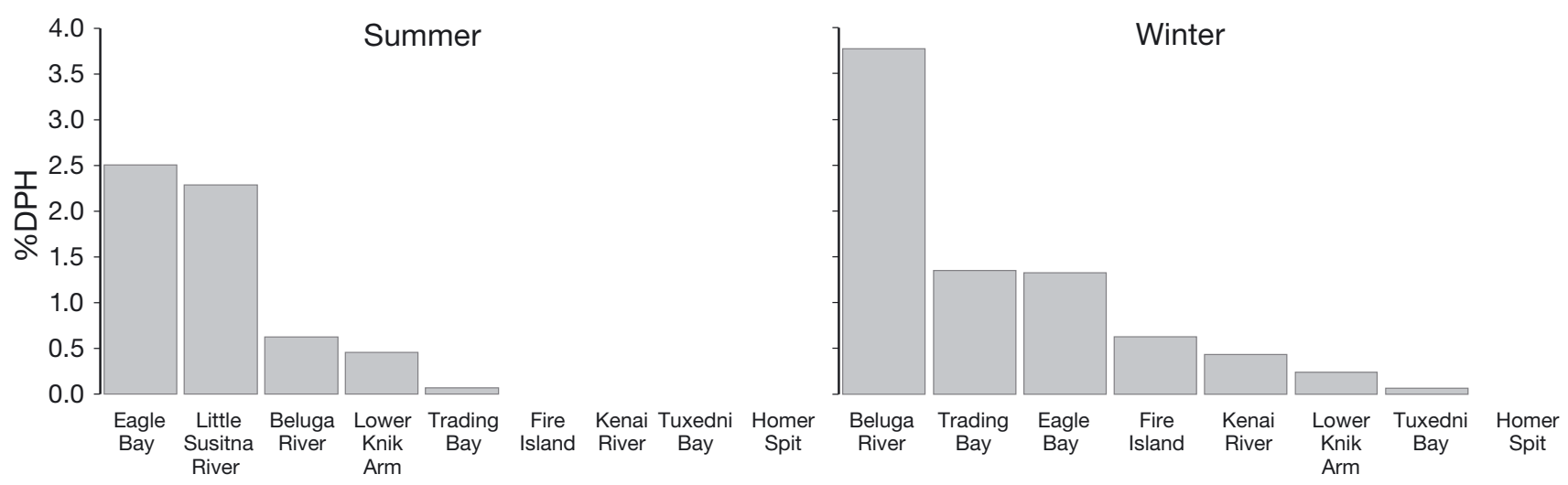

Fig. 5. Normalized beluga whale acoustic presence as median percent detection positive hours $(\% \mathrm{DPH}=\mathrm{DPH} \times 100 / \mathrm{AEH}$, where $\mathrm{AEH}=$ acoustic effort hours) during summer (May to October) and winter (November to April) at monitoring locations in Cook Inlet, Alaska, July 2008 to May 2013. Locations are ordered by decreasing \% DPH. Lower Knik Arm and Eagle Bay each include 3 different mooring deployment sites (see Fig. 2)

\subsection{Beluga whale feeding occurrence}

Based on overall C-POD results, inlet-wide foraging behavior was detected in all months except October, and substantial monthly and seasonal differences were evident (Table 3). Foraging index, the relative amount of beluga whale foraging behavior when whales were detected (Eq. 2), was low in 5 out of 6 winter months (November-April), ranging from 2-21.2 $\mathrm{mo}^{-1}$; whereas this index was substantially higher in summer, ranging from 27.6-46.2 in the first 5 mo (May-September; 0 in October). We evaluated potential masking of echolocation signals during winter months by ice noise related to thermal stress, which produces wideband impulses that overlap in frequency with beluga echolocation, but this type of signal was never identified in our C-POD data (e.g. Castellote et al. 2013). Based on feeding index results per location, the most active foraging months were during summer at Little Susitna River in May (51.1), July (84.8), and August (95.2), and at Beluga River in June (48.1), and Eagle Bay in September (37.9). Other active foraging months outside summer were April at Beluga River (38.9), and December at Trading Bay (42.9).

Foraging index values were higher in summer than winter at the upper inlet locations (Figs. 8 \& 9). Specifically, the summer foraging index at Little Susitna reached 73.5, which was the highest summer value, followed by 41.9 at Beluga River and 23.4 at Eagle Bay. The highest winter foraging index (8.5) occurred at both Beluga River and Trading Bay, followed by Tuxedni Bay (5.3) and Eagle Bay (4.0). The only other location where winter foraging was detected was lower Knik Arm, with an index of 0.9.
These results highlight how beluga whales foraged across a substantially greater area (Tuxedni Bay to Eagle Bay) in winter compared to summer.

\section{DISCUSSION}

Year-round passive acoustic monitoring was achieved successfully at the majority of our monitoring locations throughout Cook Inlet. Several moorings were not recovered in the Knik Arm region in the upper inlet due to the combination of very shallow depths, strong currents, large vegetative debris suspended in the water column, high levels of sedimentation, and extensive ice gauging in winter. However, we obtained year-round information on beluga whale Delphinapterus leucas presence and foraging behavior for the 2 areas (Lower Knik Arm and Eagle Bay; see Fig. 2 lower panel) within Knik Arm, where partial data sets (i.e. $<12$ mo) were pooled from 3 different mooring sites in each area that were deployed in close proximity; only minimal data was obtained from Eagle Bay in winter.

The detectability of beluga whale vocalizations was likely impacted by transient changes in background noise due to anthropogenic sources, as well as flow noise generated by strong current periods. However, these effects might have been relevant only in some locations. Lammers et al. (2013) found masking to be of intermediate concern for beluga whale detection in Cairn Point and Homer Spit and high at Fire Island, with seasonal variations. The average daily number of hours that beluga whale calls could have been masked by flow/mooring noise (as well as other natural and anthropogenic sound 

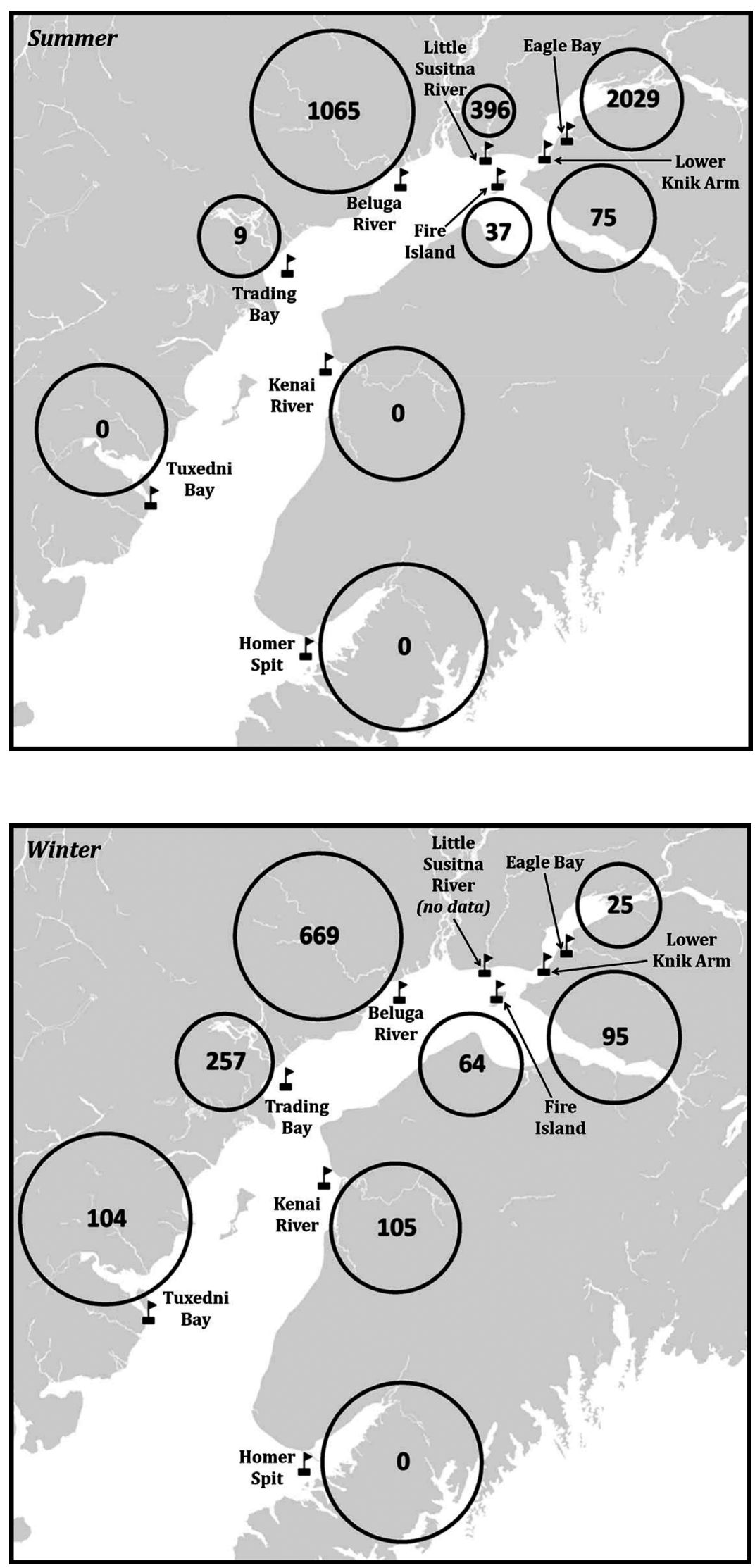

Fig. 6. Relative amount of acoustic effort hours by area represented as open circles and number of beluga detection positive hours from cetacean and porpoise detector (C-POD) and ecological acoustic recorder (EAR) combined detections within each circle obtained in summer at acoustic monitoring locations in Cook Inlet, Alaska, July 2008 to May 2013

sources in summer and winter) were quantified by Lammers et al. (2013) for these mooring sites as 0.9-3.7 h for Cairn Point, 2.3-4 h for Homer Spit, and 9.9-16.3 h for Fire Island. As discussed in Section 4.1, beluga detections in Cairn Point were lower than in upper areas of the Knik Arm, and thus in part this could be due to masking effects. However, the fact that detections were also consistently low or absent outside the periods of highest noise, together with the preference of belugas to use this part of the arm primarily around low slack periods (Markowitz \& McGuire 2007, Cornick et al. 2011), suggests that masking of beluga signals might not play a critical role in the results on this location. In the contrary, Homer Spit and Fire Island noise results are an example of how some locations in Cook Inlet are poorly suited for acoustic monitoring. Homer Spit is situated within the east coast southernmost region of the Cook Inlet beluga critical habitat. Belugas have not been sighted in this area in recent times (last sighting in dedicated surveys was

Fig. 7. Relative amount of acoustic effort hours represented as open circles and number of beluga detection positive hours from cetacean and porpoise detector (C-POD) and ecological acoustic recorder (EAR) combined detections within each circle obtained in winter at acoustic monitoring locations in Cook Inlet, Alaska, July 2008 to May 2013 
Table 3. Total number of beluga whale foraging positive minutes (FPM), by month and season, total number of detection positive hours (DPH) by month excluding time when C-POD instruments were not active, and foraging index $([\mathrm{FPM} \times 100] / \mathrm{DPH})$ for acoustic moorings deployed in Cook Inlet, Alaska, July 2008 to May 2013. Lower Knik Arm and Eagle Bay each include 3 different mooring deployment sites (see Fig. 2); only non-overlapped DPHs and FPMs are listed. Locations are ordered by higher to lower latitude; '0' corresponds to no FPM detections; '-' corresponds to no data available (area not sampled that month)

\begin{tabular}{|c|c|c|c|c|c|c|c|c|c|}
\hline & $\begin{array}{c}\text { Eagle } \\
\text { Bay }\end{array}$ & $\begin{array}{l}\text { Lower } \\
\text { Knik Arm }\end{array}$ & $\begin{array}{l}\text { Little Susitna } \\
\text { River }\end{array}$ & $\begin{array}{l}\text { Beluga } \\
\text { River }\end{array}$ & $\begin{array}{c}\text { Trading } \\
\text { Bay }\end{array}$ & $\begin{array}{l}\text { Tuxedni } \\
\text { Bay }\end{array}$ & $\begin{array}{l}\text { Total } \\
\text { FPM }\end{array}$ & $\begin{array}{l}\text { Total } \\
\text { DPH }\end{array}$ & $\begin{array}{l}\text { Foraging } \\
\text { index }\end{array}$ \\
\hline May & 0 & 0 & 48 & 0 & 0 & 0 & 48 & 104 & 46.2 \\
\hline Jun & 0 & 0 & 1 & 163 & 0 & 0 & 164 & 416 & 39.4 \\
\hline Jul & 0 & 0 & 28 & 87 & 0 & 0 & 115 & 303 & 38.0 \\
\hline Aug & 117 & 1 & 219 & 0 & 0 & 0 & 337 & 730 & 46.2 \\
\hline Sep & 39 & 0 & 4 & 0 & 0 & 0 & 43 & 156 & 27.6 \\
\hline Oct & 0 & 0 & - & 0 & 0 & 0 & 0 & 28 & 0.00 \\
\hline Summer total & 156 & 1 & 300 & 250 & 0 & 0 & 707 & 1737 & - \\
\hline Nov & 1 & 2 & - & 2 & 0 & 0 & 5 & 134 & 3.7 \\
\hline Dec & 0 & 6 & - & 1 & 6 & 0 & 13 & 210 & 6.2 \\
\hline Jan & 0 & 0 & - & 0 & 0 & 1 & 0 & 28 & 3.6 \\
\hline Feb & 0 & 0 & - & 1 & 0 & 0 & 1 & 101 & 2.0 \\
\hline Mar & 0 & 0 & - & 9 & 2 & 3 & 14 & 186 & 7.5 \\
\hline Apr & 0 & 1 & - & 21 & 0 & 0 & 22 & 104 & 21.2 \\
\hline Winter total & 1 & 9 & 0 & 34 & 8 & 3 & 55 & 763 & - \\
\hline
\end{tabular}

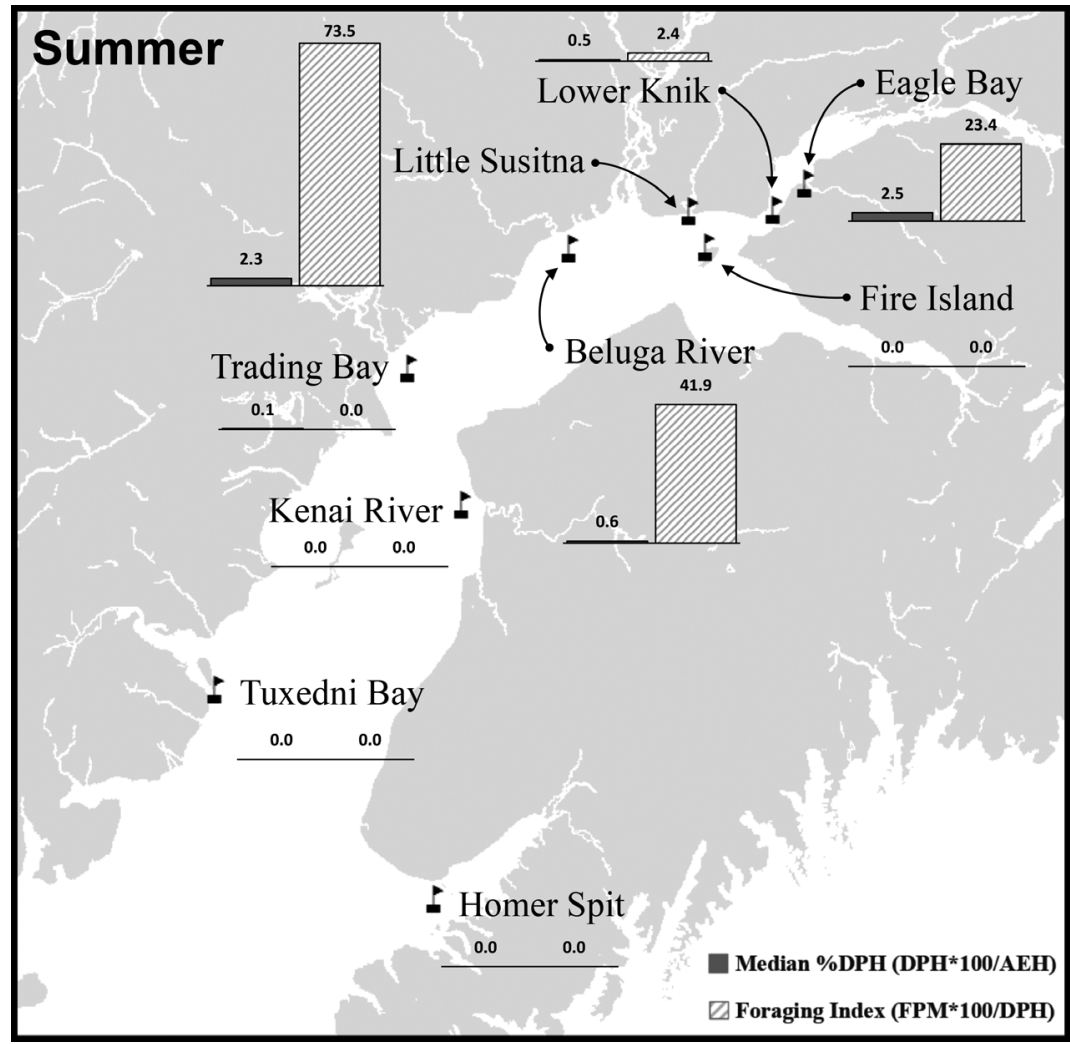

Fig. 8. Normalized beluga acoustic presence as percent detection positive hours $(\% \mathrm{DPH}=\mathrm{DPH} \times 100 / \mathrm{AEH}$, where $\mathrm{AEH}=$ acoustic effort hours $)$ and foraging in$\operatorname{dex}(\mathrm{FPM} \times 100 / \mathrm{DPH}$, where FPM = foraging positive minutes) during summer, based on acoustic monitoring data obtained during the Cook Inlet Beluga

Acoustics research program in Cook Inlet, Alaska, July 2008 to May 2013 in 1978; Shelden et al. 2015), and thus we did not expect to detect belugas at this location. The mooring at Fire Island was exposed to the main current flow in that area, and was strongly affected by flow noise. Beluga detections could have been easily missed at this location due to flow noise, thus results from this location are not discussed any further. Lammers et al. (2013) reported that for all other mooring sites, beluga whale signals were detectable during at least $80 \%$ of the recording time.

Short, acute increases of noise (i.e. ship passage) that could have had an impact in our vocalization detection results were buffered because beluga whale presence/ absence determination was based on a $1 \mathrm{~h}$ basis. Thus, much of the masking effect by transient increases in noise might have been reduced by using the period immediately before and after the acute event to determine overall beluga whale presence within that hour. Echolocation detection was not affected by flow noise or anthro- 


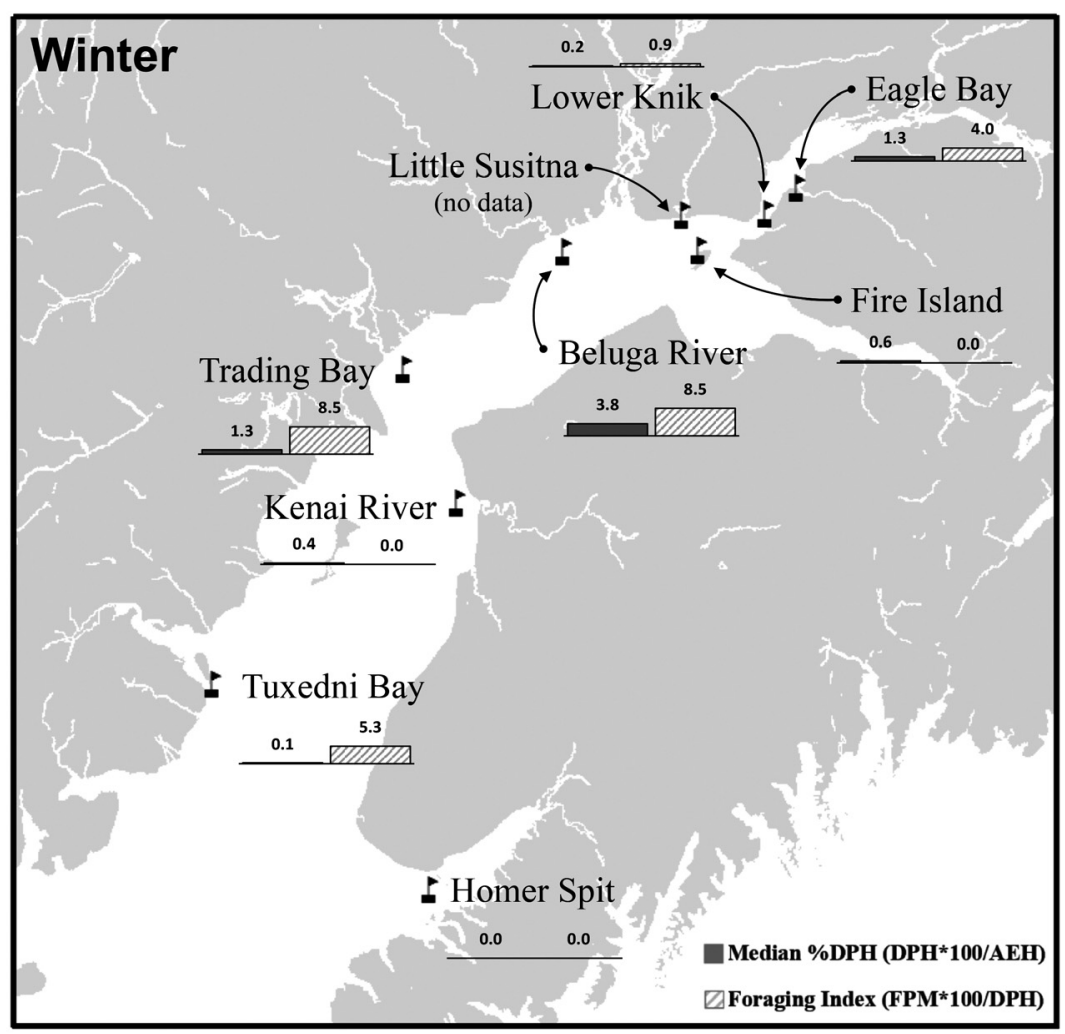

Fig. 9. Normalized beluga acoustic presence as percent detection positive hours or $(\% \mathrm{DPH}=\mathrm{DPH} \times 100 / \mathrm{AEH}$, where $\mathrm{AEH}=$ acoustic effort hours $)$ and foraging index (FPM $\times 100 / \mathrm{DPH}$, where $\mathrm{FPM}=$ foraging positive minutes) during winter, based on acoustic monitoring data obtained during the Cook Inlet Beluga Acoustics research program in Cook Inlet, Alaska, July 2008 to May 2013 the most comprehensive description of beluga seasonal distribution and foraging obtained to date. In general, during summer (MayOctober), beluga whales were detected only in upper Cook Inlet, and during winter (NovemberApril) the whales reduced their presence in the upper inlet and were detected at lower inlet locations. Further, distinct patterns within and between summer and winter seasons were observed across years at several mooring locations. Consistent with anecdotal observations, beluga foraging behavior was most prevalent during summer in upper Cook Inlet, including Knik Arm. Yet unexpectedly, during winter, foraging behavior persisted in Lower Knik Arm and Beluga River and was detected in the lower inlet (i.e. Trading Bay and Tuxedni Bay). Details of Cook Inlet beluga whale seasonal distribution and foraging behavior are discussed below, along with their importance relative to the conservation of this endangered population. pogenic noise because signal masking only occurred below the functional frequencies of the C-POD. However, in sand and gravel areas where bedload transport occurred during high currents, the C-POD data could be dominated by the impulsive nature of this natural noise source, and masking of echolocation signals might have been problematic (Castellote et al. 2016). This source of natural ultrasonic noise was found only in mooring locations inside Knik Arm and Fire Island. Cairn Point in particular was exposed to strong current flow, inducing bedload transport at peak current periods. However, as discussed above, beluga presence during peak current periods was not expected in this area of the arm. As with EAR data for Fire Island, because of the potential for masking due to bedload transport noise, C-POD results from this location are not discussed any further.

Our results represent the first continuous multiyear assessment of seasonal beluga whale presence and foraging behavior across Cook Inlet, providing

\subsection{Seasonal distribution}

Prey availability and predator avoidance likely have a strong influence on the seasonal distribution of beluga whales. For Cook Inlet, anadromous fish runs influence beluga whale distribution, particularly during summer at major river mouths where beluga whales concentrate (Moore et al. 2000). Beluga whale movements and distribution are also likely influenced by the potential for predation by transient killer whales Orcinus orca, as recently demonstrated for narwhal Mondon monocerosi (Breed et al. 2017). Given the current knowledge, the overall contribution of killer whale predation to Cook Inlet beluga mortality (at least $1 \mathrm{yr}^{-1}$ ) appears small (Shelden et al. 2003). Our acoustic monitoring effort obtained only one transient killer whale detection at Beluga River in the $5 \mathrm{yr}$ period (Castellote et al. 2016). There is a paucity of empirical data on Cook Inlet prey and predators at the temporal and spatial scales needed for making reliable inferences associ- 
ated with our whale distribution data. Reproduction might also play a role in Cook Inlet beluga seasonal distribution. It is known that other beluga populations typically concentrate in specific areas during summer for mating, and these reproductive gatherings occur on a daily basis, driven by the tidal cycle (Bel'kovich 2004, Krasnova et al. 2012). However, no information exists on habitat preferences for mating behavior of Cook Inlet belugas.

Beluga whales were often detected by only 1 of the 2 acoustic instruments (EARs and C-PODs); thus, combining the 2 simultaneously collected detection data sets enhanced the assessment of beluga whale presence. Castellote et al. (2016) provided a detailed comparison of beluga whale detection data from EARs and C-PODs in Cook Inlet, yet some discussion of this topic is warranted here. In particular, we considered acoustic effort equal across monitoring locations when either one or both instruments were sampling, recognizing beluga whale detection probability was not equal between the 2 instruments. Specifically, the detection range of the EAR (up to $3.3 \mathrm{~km}$; Lammers et al. 2013) is greater than that of the C-POD (up to $900 \mathrm{~m}$; Castellote et al. 2016) because of the stronger propagation loss of high frequency signals like echolocation clicks compared to lower frequency calls and whistles. In addition, EAR monitoring was on a $10 \%$ duty cycle whereas C-PODs monitored continuously. However, detection probability was highly variable for both instruments due to numerous environmental parameters in Cook Inlet that affect underwater sound propagation, including continuously varying water depth, salinity, temperature, and flow noise created by water currents around the hydrophones. As such, we did not consider the differential detection probability between the 2 instruments a concern in our analyses because estimating beluga call density was not our objective.

In general, our mooring data results suggest a distribution pattern in early summer that is in accordance with the $\sim 2$ wk aerial surveys conducted in late May and June from 1998-2018, which indicates that more whales were seen in the Susitna Delta area (from east of Beluga River to Little Susitna River; Fig. 1) than in the arms or the central or southern portions of Cook Inlet (Rugh et al. 2000, 2005, Shelden et al. 2013, 2015). On an annual basis, our results are also generally in accordance with the available satellite telemetry data (from 1999-2003), which indicate tagged beluga whales shifted to lower inlet areas during winter, yet occasionally spent time in the upper inlet (Hobbs et al. 2005, Shelden et al. 2018).
The summer beluga whale concentration might be driven primarily by the availability of prey, particularly at major river mouths in the presence of anadromous fish runs (Moore et al. 2000). The fact that beluga whale presence was not concentrated in winter suggests less spatially concentrated prey, or alternatively, prey concentrated in areas that were not sampled.

Weekly means of daily beluga whale DPH plots were compared across monitoring locations, seasons, and years to explore what patterns in whale distributions were evident, and how they could potentially be associated with prey. Results presented in plots from upper Knik Arm (Fig. 3A,B) document a pattern in beluga whale presence peaking during summer. In a review of the NMFS abundance surveys flown in May-June, Shelden et al. (2015) highlighted Knik Arm as an area occupied by large numbers of beluga whales during June in the 1990s through 2007, yet whales were not found in this area from 2008-2014. In contrast, our detection results show variable presence of beluga whales in Knik Arm in May and June in some of those later years (2010, 2011, 2012; Fig. 3A,B).

This inter-annual variability could be related to differences in the prey field, notably salmon runs in the rivers of Knik Arm. In fact, in Eagle River, data from 2010 showed a high number of DPHs, while data from 2011 showed a much lower number of DPHs; however, both years yielded a very similar number of DPHs in Eagle Bay North. These differences in beluga whale presence suggest that in 2011 beluga whales had less interest in Eagle River, yet maintained the same interest as in 2010 for Eagle Bay North. This could be explained if salmon runs in Eagle River, which are already relatively small (2012$2018, \bar{x}=6330$ salmon; C. Garner unpubl. data) were lower in 2011 than in 2010, but prey availability in Eagle Bay was sustained. Salmon escapement data suggests that 2011 salmon runs in Knik Arm were indeed poor (Shields \& Dupuis 2012) and it seems likely that these reductions to an already small run might have enticed belugas to spend more time in the Bay foraging on salmon bound for more productive streams in upper Knik Arm in addition to marine species like saffron cod Eleginus gracilis and starry flounder Platichthys stellatus which are found in the area (Houghton et al. 2005, Schoofs et al. 2018).

Weekly means of daily beluga whale DPHs from Little Susitna were obtained only in summer 2011, and beluga whale presence peaked at the end of June and again in August; monitoring did not begin early enough to detect when the June peak began (Fig. 3C). This bimodal distribution of beluga whale 
detections could be related to the known availability of the 2 main anadromous prey species for Cook Inlet beluga whales, eulachon Thaleichthys pacificus and Pacific salmon Oncorhynchus spp. Beluga whales switch from consuming lipid-rich eulachon in the spring to larger species such as Pacific salmon in the late spring and summer (Abookire \& Piatt 2005, Litzow et al. 2006). Overall, Eagle River had a higher maximum weekly mean of daily beluga whale DPHs than Little Susitna. Our results indicate that Eagle River is as important for belugas as Little Susitna River, if not more so, at least for the period when both rivers where concurrently sampled in 2011.

Weekly mean of daily beluga DPHs from Beluga River also showed similarities in detection patterns across years. The early spring peak, also detected at Little Susitna in May, could be explained by the occurrence of eulachon runs, and perhaps the presence of saffron cod as inferred from substantial April catches of this species in nearby lower Knik Arm (Houghton et al. 2005).

The largest peak in presence in Beluga River in June to mid-July, approximately 2 mo before the main 2011 peaks in presence in Little Susitna and Eagle Rivers, might correspond with the occurrence of the main salmon runs (Moulton 1997). The delay between peaks in beluga presence among these 3 rivers could be explained by differences in the timing of anadromous fish runs; i.e. belugas may target a different species in Eagle River than in Beluga and Little Susitna Rivers. Also, prey accessibility rather than density could play a role here; prey could be easier to capture at Beluga River during June to midJuly, and at Little Susitna and Eagle River during August to September, even if more abundant fish runs might be available in other rivers.

Weekly means of daily beluga DPHs from lower Knik Arm (i.e. Cairn Point, Point MacKenzie, and Six Mile) were surprisingly low compared to upper Knik Arm (i.e. North Eagle Bay, Eagle River, South Eagle Bay). Kendall et al. (2013) monitored beluga whales acoustically in lower Knik Arm, and also reported low acoustic detections. The authors suggested 3 possible mechanisms for the low acoustic detections in their study: (1) beluga whales reduce their vocal activity when transiting through the area; (2) beluga whale acoustic signals are masked by anthropogenic noise; and (3) beluga whales were displaced from the east to the west side of lower Knik Arm due to noise from the industrial activities nearby at the Port of Anchorage.

An alternative and more parsimonious explanation for the low echolocation detection rate in lower Knik
Arm is that belugas moved through that area relatively quickly when entering or exiting the arm and remained in the upper arm for several days or weeks before moving back out into Cook Inlet. Such a movement pattern is consistent with the substantially higher \%DPH observed in Eagle Bay and Little Susitna, compared to the much lower \%DPH in lower Knik Arm (Fig. 8). Satellite telemetry data indicates such a movement pattern may be common. Specifically, a beluga instrumented with a satellite linked time/depth recorder entered Knik Arm on 18 August 1999 and remained in Eagle Bay until 12 September 1999 (Ferrero et al. 2000). Results from satellite tagging efforts during 1999-2003 showed that approximately $50-75 \%$ of the recorded locations in August were inside Knik Arm, concentrated near Eagle River, being the month with the smallest area used by the tagged whales of all months sampled (Hobbs et al. 2005). Further, a recent detailed re-analysis of the satellite telemetry data confirms how several tagged whales exhibited this same movement pattern: whales entered Knik Arm and remained there for several days before exiting through lower Knik Arm (Shelden et al. 2018).

The \%DPH during summer was in accordance with the previously reported general concentration of whales in the upper inlet, particularly near coastal mudflats and river mouths (Calkins 1989, Smith \& Martin 1994, Moore et al. 2000, Rugh et al. 2000, Goetz et al. 2007, Hobbs et al. 2005, Shelden et al. 2015, Wolf et al. 2018). Eagle Bay (primarily influenced by Eagle River), Little Susitna, and Beluga River were the 3 river locations we monitored in the upper inlet, and their median \%DPH $(2.5,2.3$, and $0.6 \%$, respectively) were greater than all other locations (range: $0.0-0.5 \%$ ) (Fig. 5). These 3 rivers, and the Susitna River, are considered early summer foraging habitat for belugas (Rugh et al. 2000), with high concentrations observed in Knik Arm, particularly in Eagle Bay, later in summer (Huntington 2000, Hobbs et al. 2005, Shelden et al. 2015).

Prior to our study, the only available information on beluga winter distribution in Cook Inlet was from the 1999-2003 satellite telemetry studies (from 18 tagged adult males: 4 transmitted until March, 2 until April, and 1 until May; Shelden et al. 2018), and winter aerial surveys conducted in 1977-1979, 1997, and 2001-2002 (Shelden et al. 2015). This information indicates that whales continue to use the upper inlet, including Knik Arm, until November, then begin moving throughout the mid inlet and across the expansive offshore waters; areas of focal use in the upper inlet are minimal. Our acoustic results, showing 
a wider spatial distribution of median \%DPH in winter based entirely on coastal monitoring locations, match this general trend. At the 4 mid and lower inlet locations (Trading Bay, Kenai River, Tuxedni Bay, Homer Spit), beluga whales were not detected during summer other than a minimal $0.1 \%$ DPH at Trading Bay. Thus, the increase in \%DPH at Trading Bay $(1.3 \%)$ and detections at Kenai River (0.4\%) and Tuxedni Bay $(0.1 \%)$ indicates that beluga distribution in winter was substantially larger than in summer. However, beluga presence during winter was highest at Beluga River and the presence of whales at Eagle Bay was only slightly less than Trading Bay (Fig. 5), suggesting that the upper inlet might be more important during winter than previously described. The majority of our Knik Arm winter data was collected in the lower area of the arm rather than near Eagle Bay (Fig. 2), and beluga whales were present in all 6 winter months (November-April) other than February. These results match the location patterns of satellite-tagged belugas, with a relatively high probability of occurrence in Trading Bay from December-March (Hobbs et al. 2005, Shelden et al. 2018). Our results support the premise that the distribution of beluga whales in Cook Inlet is currently limited to the upper and mid-inlet during summer, and expands in winter towards the lower extent of the inlet, including common visits to Kenai River and Tuxedni Bay.

\subsection{Foraging occurrence}

Only $0.3 \%$ of all the DPHs contained foraging buzzes, which were detected at 8 of the 13 sampled locations: North Eagle Bay, Eagle River, Point MacKenzie, Cairn Point, Little Susitna River, Beluga River, Trading Bay, and Tuxedni Bay. These results suggest that foraging behavior is widespread geographically within Cook Inlet, yet is rarely detected, or that it occurs infrequently. The probability of acoustically detecting foraging behavior is very low, because echolocation signals are highly directional (Au et al. 1987), and thus foraging buzzes will only be detected by C-PODs when beluga whales echolocate towards prey in the direction of a mooring. Furthermore, our choice of $<2 \mathrm{~ms}$ for an ICI threshold is very conservative, i.e. only the terminal portion of feeding buzzes, which correspond to only the last moments before prey capture, qualified.

Seasonally, beluga foraging behavior was much more prevalent during summer (FPM $=707 ; 92.8 \%$ of all FPMs) than during winter (FPM $=55 ; 7.2 \%$ of all
FPMs), particularly at upper inlet rivers. Little Susitna had the highest foraging index, peaking in July-August and to a lesser extent in May (Table 3). These peaks could correspond to the presence of different anadromous fish runs in Little Susitna, as discussed in the previous section; specifically, both eulachon T. pacificus and Pacific salmon Oncorhynchus spp. are known beluga whale prey and are present in the river during May and August, respectively (Seaman et al. 1982, Barrett et al. 1984). Beluga River had the second highest foraging occurrence in summer. Unexpectedly, beluga foraging activity appeared to clearly alternate between the Little Susitna and Beluga rivers (Table 3). Foraging buzzes were not detected past July at Beluga River (during the summer), yet were detected during August and September in Eagle Bay, suggesting that the whales' preferred feeding habitat shifted from the Susitna Delta region into Knik Arm by late summer. Recent results from aerial surveys conducted in 2013 and 2014 during the open water season (April-October), conducted by Apache Alaska Corporation as part of their marine mammal monitoring protocols, provided a similar distribution of beluga concentration areas, with a strong relationship to the availability and distribution of fish prey species (Wolf et al. 2018).

The spatial pattern in foraging described above matches the distribution pattern described in the previous section; however, the highest foraging index value was at Little Susitna, whereas the highest beluga presence was at Eagle Bay (Fig. 8), a difference likely related to the location of moorings. First, the mooring was deployed well inside the Little Susitna River, approximately $4 \mathrm{~km}$ upstream from the mouth, in contrast to the Eagle River mooring that was deployed 0.1-0.3 km outside the mouth (in Eagle Bay) in deeper waters in an attempt to be maintained overwinter. Second, the relatively small data sets from the 3 moorings in Eagle Bay (Eagle Bay North, Eagle Bay South, and Eagle River mouth) were pooled, and thus data from 2 moorings relatively far ( 2-4 km) from Eagle River, where less or no foraging behavior occurred, is included. Thus, Eagle Bay beluga whale detection likely included transiting behavior to/from the main foraging area at the mouth of Eagle River rather than just foraging behavior.

Overall foraging index values for winter were much lower than summer, 0-8.5 vs. 0-73.5 respectively (Figs. $8 \& 9$ ), which confirms that for the 13 locations we monitored there is no evidence for concentrated foraging in winter at the levels observed during summer in upper Inlet rivers. Hobbs et al. (2005) reported that from December through March movements of 4 
adult male beluga whales covered a broad area in a random manner, without concentrating in any particular area, consistent with our acoustic detection results. During winter, beluga whales may have foraged offshore (i.e. mid-Inlet) on more dispersed prey (Moore et al. 2000, Goetz et al. 2012), but we did not monitor offshore waters. Goetz et al. (2012) described the highest concentration of slow transit, presumably indicative of increased foraging success, in Knik Arm during June-November, shifting to Chickaloon Bay during December-May, an area that was not monitored acoustically. Surprisingly, our acoustic results show the highest foraging index in winter in Trading Bay in December, even though beluga presence and FPMs were highest at Beluga River. This contradictory result is from beluga whales spending relatively little time in Trading Bay, yet when present in that area they often engaged in foraging behavior. In contrast, beluga whales visited Beluga River more than twice as often as Trading Bay, yet engaged in foraging behavior proportionally less frequently.

For winter, the highest foraging index occurred during April ( $\mathrm{n}=21$ ), at Beluga River, with minimal foraging occurrence during the other winter months (Table 3). The relatively high foraging index in April was the earliest sign of foraging occurrence throughout the winter months, and is likely related to the presence of eulachon, which are known to spawn as early as January (Moffitt et al. 2002), and possibly saffron cod, which was identified as a potential beluga prey species during April in nearby Knik Arm (Houghton et al. 2005). Little knowledge is available on potential beluga whale prey species in Knik Arm in December, but the review by Rodrigues et al. (2006) suggests longfin smelt Spirinchus thaleichthys and saffron cod could be present in this area during the winter.

In conclusion, the CIBA research program succeeded in the use of passive acoustics as a long-term method to monitor Cook Inlet beluga whales for a period of 5 yr (2008-2013). Specifically, social vocalizations and echolocation activity of beluga whales were obtained, allowing the description of spatial shifts in beluga presence seasonally and annually throughout their critical habitat. Beluga whales appeared concentrated in the upper inlet year-round, but particularly feeding in river mouths from AprilDecember, shifting their geographical foraging preferences from the Susitna River region towards Knik Arm in mid-August, and dispersing towards the mid inlet throughout the winter. The gathered information on seasonal distribution, in particular winter (October-April) distribution, foraging behavior de- tails, and consistent within-season use patterns across years at some locations, represents a substantial contribution to knowledge of beluga whale ecology in Cook Inlet.

Acknowledgements. Special thanks are due to Dave McKay and Bill Choate, the 2 charter vessel operators whose efforts were instrumental in the deployment and recovery of acoustic moorings in Cook Inlet during the study. Tom Gage shared warehouse space at ADF\&G Anchorage to service and store our mooring equipment. Kim Shelden helped prepare Fig. 1; John Skinner and Christine Schmale helped prepare Figs. 3, 4, 6 \& 7 and initial versions of Figs. 5, 8 \& 9. Anne Rosinski and Gadea Pérez-Andújar assisted in EAR data analysis. Amber Stephens, Carly Wickhem, Kori Blakely, Merra Howe, Natalie Rouse, Marissa Cent, Lisa Neyman, Marcus Mustin, Cory Walch, and Christie Osburn participated in the JBER Conservation Department's acoustics fieldwork program, including Eagle Bay mooring deployments and recoveries. Journal Editor Mike Noad and 3 anonymous reviewers provided many insightful comments that improved this manuscript. Funding for this research was provided by National Marine Fisheries Service Grant No. NA07NMF4390364, and US Department of Defense Contract No. W911KB-11-P-0037. Field work was conducted under NOAA Scientific Research Permit 14245 issued to the NMFS Marine Mammal Laboratory. This publication was partially funded by the Joint Institute for the Study of Atmosphere and Ocean (JISAO), University of Washington, under NOAA Cooperative Agreement NA15OAR4320063 (2015-2020). Any use of trade, firm, or product names is for descriptive purposes only and does not imply endorsement by the US Government.

\section{LITERATURE CITED}

Abookire AA, Piatt JF (2005) Oceanographic conditions structure forage fishes into lipid-rich and lipid-poor communities in lower Cook Inlet, Alaska, USA. Mar Ecol Prog Ser 287:229-240

Au WWL (1993) The sonar of dolphins. Springer, New York, NY

Au WWL, Penner RH, Turl CW (1987) Propagation of beluga echolocation signals. J Acoust Soc Am 82:807-813

Barrett BM, Thompson FM, Wick SN (1984) Adult anadromous fish investigations: May-October 1983. Susitna Hydro Aquatic Studies, Report No. 1. APA Document No. 1450. Alaska Department of Fish and Game, Anchorage, AK

Bel'kovich VM (2004) Beluga whale of the European north: the latest research. Rybn Khoz 2:32-34

Breed GA, Matthews CJD, Marcoux M, Higdon JW and others (2017) Sustained disruption of narwhal habitat use and behavior in the presence of Arctic killer whales. Proc Natl Acad Sci USA 114:2628-2633

Calkins DG (1989) Status of belukha whales in Cook Inlet. In: Jarvela LE, Thorsteinson LK (eds) Proceedings of the Gulf of Alaska, Cook Inlet, and North Aleutian Basin information update meeting, 7-8 February 1989, Anchorage, AK. US Department of Commerce, NOAA, Outer Continental Shelf Environmental Assessment Program, Anchorage, AK, p 109-112

Castellote M, Leeney RH, O'Corry-Crowe G, Lauhakangas $\mathrm{R}$ and others (2013) Monitoring white whales (Delphina- 
pterus leucas) with echolocation loggers. Polar Biol 36: 493-509

Castellote M, Small RJ, Lammers MO, Jenniges JJ, Mondragon J, Atkinson S (2016) Dual instrument passive acoustic monitoring of belugas in Cook Inlet, Alaska. J Acoust Soc Am 139:2697-2707

Cornick L, Love S, Pinney L, Smith C, Zartler Z (2011) Distribution, habitat use and behavior of Cook Inlet beluga whales and other marine mammals at the Port of Anchorage. Marine terminal redevelopment project, JuneNovember 2011. Scientific Marine Mammal Monitoring Program Annual Report. US Department of Transportation Maritime Administration and Port of Anchorage, Anchorage, AK

DeRuiter SL, Bahr A, Blanchet MA, Hansen SF and others (2009) Acoustic behaviour of echolocating porpoises during prey capture. J Exp Biol 212:3100-3107

Ferrero RC, DeMaster DP, Hill PS, Muto M (2000) Alaska marine mammal stock assessments, 2000. NOAA Tech Memo NMFS-AFSC-119

Goetz KT, Rugh DJ, Read AJ, Hobbs RC (2007) Habitat use in a marine ecosystem: beluga whales Delphinapterus leucas in Cook Inlet, Alaska. Mar Ecol Prog Ser 330:247-256

Goetz KT, Robinson PW, Hobbs RC, Laidre KL, Huckstadt LA, Shelden KEW (2012) Movement and dive behavior of beluga whales in Cook Inlet, Alaska. AFSC Proc Rep 2012-03. Alaska Fisheries Science Center, Seattle, WA

* Griffin DR, Webster FA, Michael CR (1960) The echolocation of flying insects by bats. Anim Behav 8:141-154

Herzing DL (1995) Vocalizations and associated underwater behavior of free-ranging Atlantic spotted dolphins, Stenella frontalis and bottlenose dolphins, Tursiops truncatus. Aquat Mamm 22:61-79

Hill PS, DeMaster DP (1998) Alaska marine mammal stock assessments. NOAA Tech Memo NMFS-AFSC-97

Hobbs RC, Laidre KL, Vos DJ, Mahoney BA, Eagleton M (2005) Movements and area use of belugas, Delphinapterus leucas, in a subarctic Alaskan estuary. Arctic 58:331-340

Hobbs RC, Shelden KEW, Vos DJ, Goetz KT, Rugh DJ (2006) Status review and extinction assessment of Cook Inlet belugas (Delphinapterus leucas). AFSC Proc Rep 2006-16

Houghton J, Starkes J, Chambers M, Ormerod D (2005) Marine fish and benthos studies in Knik Arm, Anchorage, Alaska. Report prepared for the Knik Arm Bridge and Toll Authority, and HDR Alaska. Pentec Environmental, Edmonds, WA

Huntington HP (2000) Traditional knowledge of the ecology of belugas, in Cook Inlet, Alaska. Mar Fish Rev 62: 134-140

Johnson M, Madsen PT, Zimmer WMX, Aguilar A, Tyack P (2004) Beaked whales echolocate for prey. Proc R Soc B 271:S383-S386

Kendall LS, Širović A, Roth EH (2013) Effects of construction noise on the Cook Inlet beluga whale (Delphinapterus leucas) vocal behavior. Can Acoust 41:3-13

Koschinski S, Diederichs A, Amundin M (2008) Click train patterns of free-ranging harbour porpoises acquired using T-PODs may be useful as indicators of their behaviour. J Cetacean Res Manag 10:147-155

Krasnova V, Chernetsky AD, Kirillova OI, Bel'kovich VM (2012) The dynamics of the abundance, age, and sex structure of the Solovetsky reproductive gathering of the beluga whale Delphinapterus leucas (Onega Bay, White Sea). Russ J Mar Biol 38:218-225
Lammers MO, Castellote M, Small RJ, Atkinson S and others (2013) Passive acoustic monitoring of Cook Inlet beluga whales (Delphinapterus leucas). J Acoust Soc Am 134:2497-2504

Litzow MAK, Bailey KM, Prahl FG, Heintz R (2006) Climate regime shifts and reorganization of fish communities: the essential fatty acid limitation hypothesis. Mar Ecol Prog Ser 315:1-11

Mahoney B, Shelden K (2000) Harvest history of belugas, Delphinapterus leucas, in Cook Inlet, Alaska. Mar Fish Rev 62:124-133

Markowitz TM, McGuire TL (2007) Temporal-spatial distribution, movements and behavior of beluga whales near the Port of Anchorage, Alaska. LGL Alaska Research Associates Report. Integrated Concepts and Research Corporation and US Department of Transportation Maritime Administration, Anchorage, AK

Miller LA, Pristed J, Moshl B, Surlykke A (1995) The clicksounds of narwhals (Monodon monoceros) in Inglefield Bay, Northwest Greenland. Mar Mamm Sci 11:491-502

Moffitt S, Marston B, Miller M (2002) Summary of eulachon research in the Copper River delta, 1998-2002. Regional Information Report No. 2A02-34. Alaska Department of Fish and Game, Anchorage, AK

Moore SE, DeMaster DP (2000) Cook Inlet belugas, Delphinapterus leucas: status and overview. Mar Fish Rev 62:1-5

Moore SE, Shelden KEW, Litzky Mahoney BA, Rugh DJ (2000) Beluga whale, Delphinapterus leucas, habitat associations in Cook Inlet, Alaska. Mar Fish Rev 62:60-80

Moulton LL (1997) Early marine residence, growth, and feeding by juvenile salmon in northern Cook Inlet. Alsk Fish Res Bull 4:154-177

*Murray SO, Mercado E, Roitblat HL (1998) Characterizing the graded structure of false killer whale (Pseudorca crassidens) vocalizations. J Acoust Soc Am 104:1679-1688

NMFS (National Marine Fisheries Service) (2000) Designating the Cook Inlet, Alaska, stock of beluga whale as depleted under the Marine Mammal Protection Act (MMPA). Fed Regist 65:34590-34597

NMFS (2008a) Endangered and threatened species; endangered status for the Cook Inlet beluga whale. Fed Regist 73:62919-62930

NMFS (2008b) Conservation plan for the Cook Inlet beluga whale (Delphinapterus leucas). National Marine Fisheries Service, Juneau, AK

NMFS (2016) Recovery plan for the Cook Inlet beluga whale (Delphinapterus leucas). National Marine Fisheries Service, Juneau, AK

* O'Corry-Crowe GM, Suydam RS, Rosenberg A, Frost KJ, Dizon AE (1997) Phylogeography, population structure and dispersal patterns of the beluga whale Delphinapterus leucas in the western Nearctic revealed by mitochondrial DNA. Mol Ecol 6:955-970

\% Quakenbush LT, Suydam RS, Bryan AL, Lowry LF, Frost KJ, Mahoney BA (2015) Diet of beluga whales, Delphinapterus leucas, in Alaska from stomach contents, March-November. Mar Fish Rev 77:70-84

Rodrigues R, Nemeth M, Markowitz T, Funk D (2006) Review of literature on fish species and beluga whales in Cook Inlet, Alaska. Final report, LGL Alaska Research Associates. DRven Corporation, Anchorage, AK

* Roy N, Simard Y, Gervaise C (2010) 3D tracking of foraging belugas from their clicks: experiment from a coastal hydrophone array. Appl Acoust 71:1050-1056 
Rugh DJ, Shelden KEW, Mahoney BA, Smith BK, Litzky LK, Hobbs RC (2000) Distribution of belugas, Delphinapterus leucas, in Cook Inlet, Alaska, during June/July, 19932000. Mar Fish Rev 62:6-21

Rugh DJ, Shelden KEW, Sims CL, Mahoney BA, Smith BK, Litzky LK, Hobbs RC (2005) Aerial surveys of belugas in Cook Inlet, Alaska, June 2001, 2002, 2003, and 2004. NOAA Tech Memo NMFS-AFSC-149

Rugh DJ, Shelden KEW, Hobbs RC (2010) Range contraction in a beluga whale population. Endang Species Res 12:69-75

Schoofs C, Garner C, Blakely K, Osburn C (2018) Stream and lake habitat year three field report, Joint Base Elmendorf-Richardson, Alaska. Colorado State University-Center for Environmental Management of Military Lands. Prepared for $673^{\text {rd }}$ Civil Engineer Squadron, Civil Engineer Installation Management, Anchorage, AK

Seaman GA, Lowry LF, Frost KJ (1982) Foods of belukha whales (Delphinapterus leucas) in western Alaska. Cetology 44:1-19

Shelden KEW, Wade PR (2019) Aerial surveys, distribution, abundance, and trend of belugas (Delphinapterus leucas) in Cook Inlet, Alaska, June 2018. AFSC Proc Rep 201909, Alaska Fisheries Science Center, Seattle, WA

Shelden KEW, Rugh DJ, Mahoney BA, Dahlheim ME (2003) Killer whale predation on belugas in Cook Inlet, Alaska: implications for a depleted population. Mar Mamm Sci 19:529-544

Shelden KEW, Rugh DJ, Goetz KT, Sims L and others (2013) Aerial surveys of beluga whales, Delphinapterus leucas,

Editorial responsibility: Mike Noad,

Gatton, Queensland, Australia in Cook Inlet, Alaska, June 2005 to 2012. NOAA Tech Memo NMFS-AFSC-263

Shelden KEW, Goetz KT, Rugh DJ, Calkins DG, Mahoney BA, Hobbs RC (2015) Spatio-temporal changes in beluga whale, Delphinapterus leucas, distribution: results from aerial surveys (1977-2014), opportunistic sightings (1975-2014), and satellite tagging (1999-2003) in Cook Inlet, Alaska. Mar Fish Rev 77:1-60

Shelden KEW, Goetz KT, Hobbs RC, Hoberecht LK and others (2018) Beluga whale, Delphinapterus leucas, satellitetagging and health assessments in Cook Inlet, Alaska, 1999 to 2002. NOAA Tech Memo NMFS-AFSC-369

Shields P, Dupuis A (2012) Upper Cook Inlet commercial fisheries annual management report, 2011. Fishery Management Report No. 12-25. Alaska Department of Fish and Game, Anchorage, AK

Smith TG, Martin AR (1994) Distribution and movements of belugas, Delphinapterus leucas, in the Canadian High Arctic. Can J Zool 68:359-367

*Verfuß UK, Miller LA, Pilz PKD (2009) Echolocation by two foraging harbour porpoises (Phocoena phocoena). J Exp Biol 212:823-834

*Wisniewska DM, Johnson M, Nachtigall PE, Madsen PT (2014) Buzzing during biosonar-based interception of prey in the delphinids Tursiops truncatus and Pseudorca crassidens. J Exp Biol 217:4279-4282

*Wolf N, Harris BP, Richard N, Suresh AS, Lomac-MacNair K, Parker L (2018) High-frequency aerial surveys inform the seasonal distribution of Cook Inlet beluga whales. Wildl Soc Bull 42:577-586

Submitted: January 14, 2019; Accepted: December 20, 2019 Proofs received from author(s): February 8, 2020 